\title{
CUSTOMER RESPONSE TOWARDS SMART PHONES PURCHASE: VERIFICATION FROM STRUCTURAL EQUATION MODELING
}

\author{
Sajeeb Kumar Shrestha*
}

\begin{abstract}
This research attempts to examine the customer response towards smart phone purchase in the Nepalese context. The aim of the study was to measure the important factors that affect to consumer purchase intention, brand extension attitude and pay premium price. Descriptive and causal research design was applied in this research. Structured questionnaires were administered for validating the measurement model and testing the structural model for customer response dimensions. It was found brand name, marketing activities, and subjective norms are the most influential factors for customer response of smart phones for purchase intention, brand extension attitude and premium price.
\end{abstract}

Key words: Purchase intention, brand extension and SEM.

\section{INTRODUCTION AND OBJECTIVE}

Consumer behavior is the study of how a consumer select, evaluate and purchase the product. Consumer purchases the product for individual consumption or household use. It is the buying behavior of an ultimate consumer. Consumer behavior involves activity of an individual consumer who evaluates, select, consume and dispose of goods and services (Loudon \& Bitta, 1993).

Mobile phones are the indispensable part of people. It plays a leading in people's life. Every people from younger to old are using mobile phones. There is increasing popularity of mobile phones day by day. Mobile phones are spread very fast in the consumer markets (Comer \& Wikle, 2008). Competition is very strong in the mobile phone markets. So, marketers should conduct research activities to identify the factors affecting mobile phone purchases (Das, 2012).

Brand name is a name, design, symbol or any features that differentiates seller's products from competitors (Keller, 1993). Brand creates value in the markets. It is more than image and words. Philips (1998)

* Dr. Shrestha is Lecturer in Shanker Dev Campus, Putali Sadak, TU. 
argued it is trademark that delivers promise and trust. It is the total of all the marketing programs (Keller, 2003). Brand means the hidden product attributes that is hard to crack (Kapferer, 1997).

After sales service is provided after the product is sold to the customers. Customers can assure that what are the services they will get after the product is bought. Product Warranty and guarantee and other services are given to the customers after purchase. It supports to start new business and enhance customer loyalty. It provides customer value.

Marketing activities are consists all the activities like product design, packaging, supply chain, channel management, pricing and promotion of the product. Marketers perform marketing activities to satisfy customer needs. It inspires marketers to do for the customers (Solomon \& Rabolt, 2009).

Price is the money paid for the product bought (Kotler \& Armstrong, 2010). Price should create value for the products. It should be different than competitors. Price discount, low price, competitive pricing are some strategies marketers use to capture the markets (Kotler \& Keller, 2012). When price become low to another products purchase intention become high (Isabella, 2012). People signal price as a matter of quality (Scitovsky, 1945). Product compatability means the product perfectly fit with customers' interest. Product compatability should also fit with consumer demand (Gatignon \& Robertson, 1985). Product should be compatible to the markets before setting the price (Farrell \& Saloner, 1985).Subjective norms are the groups, friends, family members, spouses, relatives, and friends' influence towards purchasing the product (Kotler \& Keller, 2012). Social groups influence people while buying the product. Before taking purchase decision customer take insight of social groups to reduce cognitive dissonance. Market trend is also important for choosing products (Osman, 2012). Product features are the attributes of the product that will satisfy customer needs and wants (Kotler \& Keller, 2012). It is product design, size, color, weight and other specifications.

It is the chance that consume will purchase or consume the product in the future. If purchase intention is increased the chance of being purchased is also increasing (Dodds, Monroe \& Grewal, 1991; Schiffman $\&$ Kanuk, 2007). It can be used as a major tool for forecasting consumer behavior. Positive purchase intention leads to positive brand commitment that consumers do actual purchase activities (Fishbein \& Ajzen, 1975; 
Schiffman \& Kanuk, 2007). Consumer purchase not only purchase the brand but has developed favorable attitude to others brands in the category (Porter, 1974).Brand extension means extension of an established brand name to introduce new product (Keller, 2003). It can be line extension and category extension. Line extension means using a sub-brand to target market segment within the same product category. In category extension company uses the parent brand in a different product category. Price premium is the total of consumers' willingness to pay more for the brand than other relevant brand (Aaker, 1996). It can be either positive or negative impact to the brand. It is signal of brand strength.

Mohan (2014) examined branding, product design, product performance and price has significant influence on people's buying decision process. Malviya, Saluja, and Thakur (2013) found price, brand preference, social influence and features having a dominant influence on the purchase decision of consumers. Lay-Yee, Kok-Siew and Yin-Fah (2013) confirmed that a significant relationship between purchasing decision with brand concern, convenience concern, dependency concern, price concern, and product features concern and social influence concern. Dziwornu (2013) investigated advanced product features such as internet browsing and durability or quality of mobile phone handsets are the two main factors that are likely to positively and significantly affect mobile phone purchase decision. Khan and Rohi (2013) found that product quality, brand image and family and friends influence were the key variables that influence the brand choice of youths for mobile handset purchase.

Peoples are purchasing smart phones and show the certain behavior pattern that need to be studied. Consumers prefer branding, product design, product performance, price, subjective norms, product features (Dziwornu, 2013; Khan \& Rohi, 2013; Lay-Yee, 2013; Malviya, 2013 \& Mohan, 2014). Consumer response can be shown as purchase intention, brand extension attitude and pay premium price. As there is lack of research conducted in consumer response towards smart phone purchase. The purpose of the study is to analyze interrelationships among consumer responses/behavior in the Nepalese smart phone markets. The following research questions were raised for the study:

What are the important factors that affects to consumer purchase intention?

What are the important factors that affect to brand extension attitude? 
What are the important factors that affect to pay premium price?

The Objectives of the Study are as follows:

- To measure the important factors that affect to consumer purchase intention.

- To examine the important factors that affect to brand extension attitude.

- To analyze the important factors that affect to pay premium price.

Figure 1: Research Framework

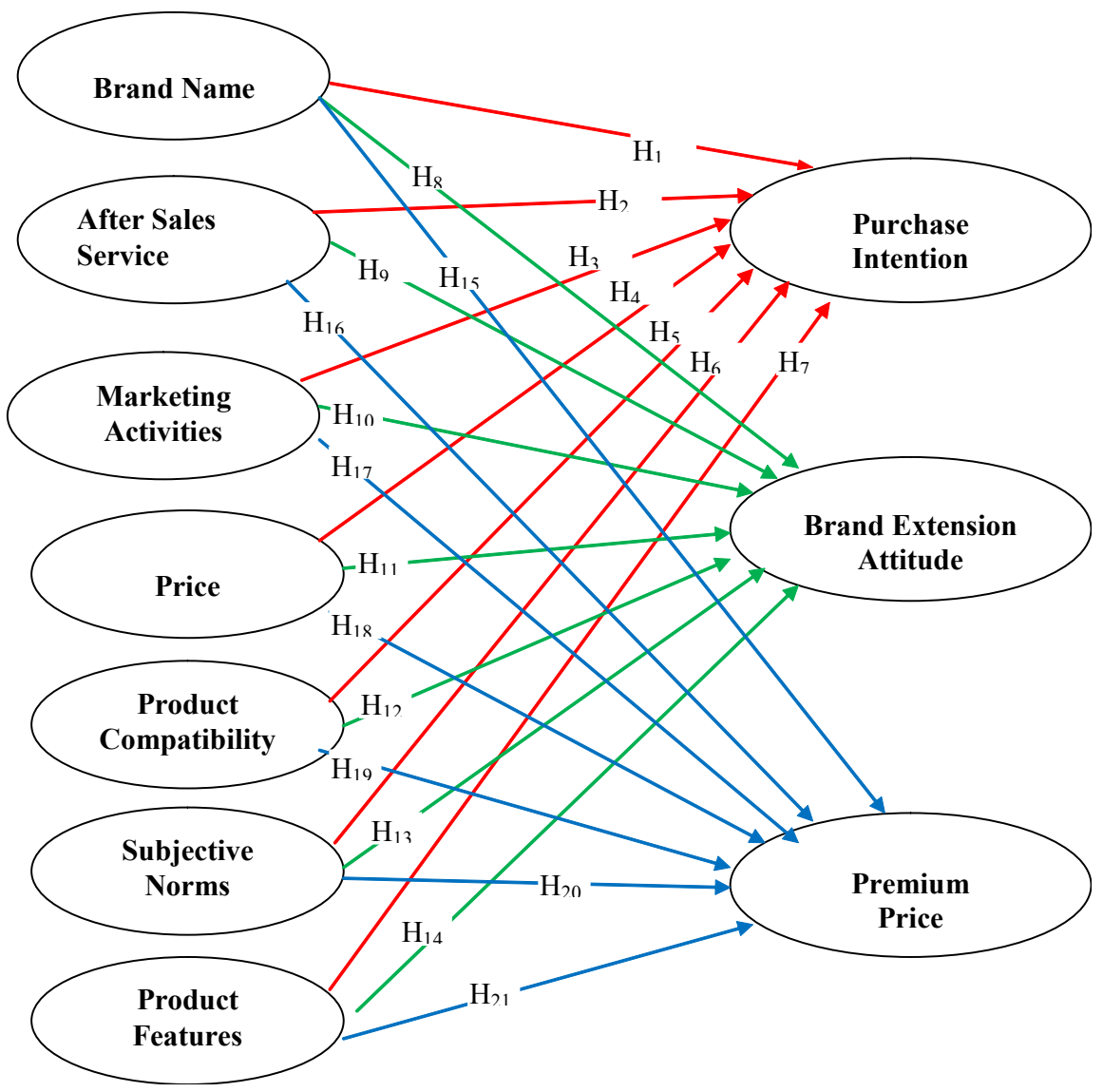

\section{HYPOTHESIS}

$\mathrm{H}_{1}$ : Brand name has influence on purchase intention.

$\mathrm{H}_{2}$ : After sales service has influence on purchase intention. 
$\mathrm{H}_{3}$ : Marketing activities has influence on purchase intention.

$\mathrm{H}_{4}$ : Price has influence on purchase intention.

$\mathrm{H}_{5}$ : Product compatability has influence on purchase intention.

$\mathrm{H}_{6}$ : Subjective norms have influence on purchase intention.

$\mathrm{H}_{7}$ : Product features have influence on purchase intention.

$\mathrm{H}_{8}$ : Brand name has influence on brand extension attitude.

$\mathrm{H}_{9}$ : After sales service has influence on brand extension attitude.

$\mathrm{H}_{10}$ : Marketing activities has influence on brand extension attitude.

$\mathrm{H}_{11}$ : Price has influence on brand extension attitude.

$\mathrm{H}_{12}$ : Product compatability has influence on brand extension attitude.

$\mathrm{H}_{13}$ : Subjective norms have influence on brand extension attitude.

$\mathrm{H}_{14}$ : Product features have influence on brand extension attitude.

$\mathrm{H}_{15}$ : Brand name has influence on premium price.

$\mathrm{H}_{16}$ : After sales service has influence on premium price.

$\mathrm{H}_{17}$ : Marketing activities has influence on premium price.

$\mathrm{H}_{18}$ : Price has influence on premium price.

$\mathrm{H}_{19}$ : Product compatability has influence on premium price.

$\mathrm{H}_{20}$ : Subjective norms have influence on premium price.

$\mathrm{H}_{21}$ : Product features have influence on premium price.

\section{METHODOLOGY}

The aim of the study was to examine the interrelationship among consumer behavior in the Nepalese smart phone markets. To clarify the concept and to establish the causal relationship, descriptive and causal research design were applied in this study. Constructs were derived from reviewing the literature. Population of the study was the respondents who own different brand of smart phones in the Kathmandu City. Sample size was 290 respondents in Kathmandu City. Convenience samples were taken to fulfill the objectives of the study. Data were obtained through structured questionnaires. Questionnaires were administered to respondents in 
Kathmandu City. The questionnaire contained of Likert-type statements that were used to collect responses towards disagreement to agreement using five-point scale (where $1=$ strongly disagree and $5=$ strongly agree). Exogenous constructs used in this study were brand name, after sales service, marketing activities, price, product compatability, subjective norms, product features. Endogenous constructs used in this study were purchase intention, brand extension attitude and premium price.

The study showed that 53.4 percent of the respondents were male and 46.6 percent of the respondents were female. Majority of the respondents were bachelor graduates having 59.3 percent and master graduates having 26.9 percent. Large number of respondents was representing 67.6 percent on 15 to 25 year age category, followed by 21.7 percent in 25 to 35 age category. For data analysis and testing of hypothesis, Structural Equation Modeling (SEM) was used. SPSS 20 and AMOS 20 statistical and graphical software was used for data analysis. The study was based on survey data. Primary data were taken for this research. Study was conducted in Kathmandu City only.

\section{DATA ANALYSIS}

\section{Exploratory factor analysis (EFA)}

Exploratory factor analysis is run to extract the factors/constructs (Hair, Anderson, Tatham, \& Black, 1998). Scales items were rotated through Varimax Rotation and formed a construct with no cross loadings. EFA gives refined constructs that is used for confirmatory factor analysis (CFA). Bartlett's test of Sphericity (Chi-square 3069.3) which was significant (p-value $=0.000<0.05)$ and $\mathrm{KMO}$ value was .747. It was said that sample numbers were adequate for the study. Ten factors were extracted that explained 64.063 of total variance. After scale items rotated from Varimax Rotation, scales items above 0.5 were grouped into the related constructs. Scales items below were dropped from the study. Extracted factors were named were termed as brand name, after sales service, marketing activities, price, product compatability, subjective norms, product features, purchase intention, brand extension attitude and premium price. 
Table 1: Rotated Component Matrix

\begin{tabular}{|l|c|c|c|c|c|c|c|c|c|c|}
\hline \multicolumn{7}{|c|}{ Rotated Component Matrix } \\
\hline & \multicolumn{7}{|c|}{ Component } \\
\hline & 1 & 2 & 3 & 4 & 5 & 6 & 7 & 8 & 9 & 10 \\
\hline Cb14 & .843 & & & & & & & & & \\
\hline Cb15 & .842 & & & & & & & & & \\
\hline Cb13 & .772 & & & & & & & & & \\
\hline Cb16 & .762 & & & & & & & & & \\
\hline Cb3 & .654 & & & & & & & & & \\
\hline brand2 & & .674 & & & & & & & & \\
\hline brand1 & & .665 & & & & & & & & \\
\hline Prc1 & & .658 & & & & & & & & \\
\hline brand3 & & .566 & & & & & & & & \\
\hline Pf1 & & .561 & & & & & & & & \\
\hline Asa3 & & & .810 & & & & & & & \\
\hline Asa2 & & & .776 & & & & & & & \\
\hline Asa1 & & & .754 & & & & & & & \\
\hline Cb9 & & & & .759 & & & & & & \\
\hline Cb8 & & & & .712 & & & & & & \\
\hline Cb10 & & & & .701 & & & & & & \\
\hline mark2 & & & & & .789 & & & & & \\
\hline mark1 & & & & & .748 & & & & & \\
\hline mark3 & & & & & .703 & & & & & \\
\hline Cb6 & & & & & & .755 & & & & \\
\hline Cb7 & & & & & & .698 & & & & \\
\hline brand4 & & & & & & & & & & \\
\hline pri3 & & & & & & & .794 & & & \\
\hline pri2 & & & & & & & .736 & & & \\
\hline pri4 & & & & & & & .576 & & & \\
\hline Prc2 & & & & & & & & .856 & & \\
\hline Prc3 & & & & & & & & .683 & & \\
\hline Prc4 & & & & & & & & .574 & & \\
\hline Sn1 & & & & & & & & & .717 & \\
\hline Sn3 & & & & & & & & & .707 & \\
\hline Sn2 & & & & & & & & & .617 & \\
\hline Pf3 & & & & & & & & & & .860 \\
\hline Pf2 & & & & & & & & & & .818 \\
\hline Extraction Method: Principal Component Analysis. \\
Rotation Method: Varimax with Kaiser Normalization.
\end{tabular}




\section{Confirmatory factor analysis (CFA)}

Confirmatory factor analysis measures the validity and reliability of the latent variable as well as the model proposed. It shows the relations among factors, and the relations between the factors and the observed variables. CFA is run to examine the fitness and validity of the measurement model (Anderson \& Gerbing, 1988). The model was fairly fitted as, CMIN/ $\mathrm{DF}=1.804, \mathrm{GFI}=0.911, \mathrm{CFI}=0.902$, and RMSEA $=0.041$ (Byrne, 2001, Hair, 1998; Joreskog \& Sorbom, 1993). So, it was said that the model was fairly fitted.

Figure 2: Measurement Model

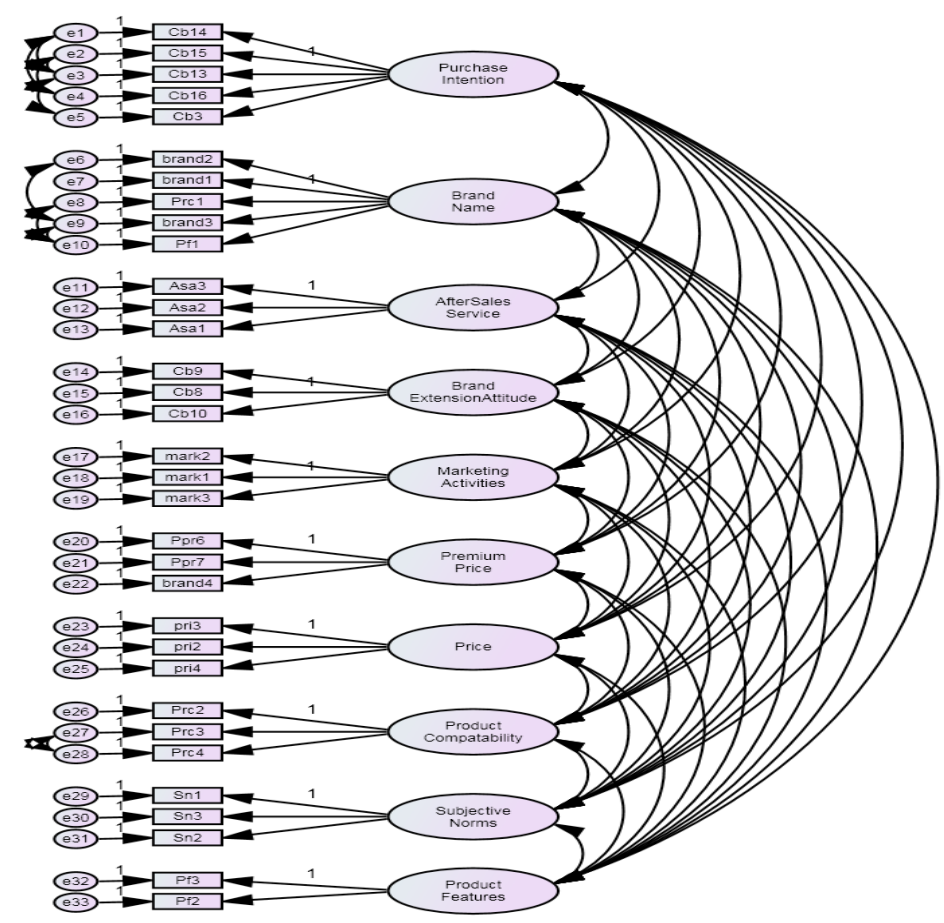

Testing the validity is the major benefit of running CFA. For validity purpose, discriminant validity and convergent validity were examined for the measurement model. If AVE (Average Variance Explained) of the construct should be above 0.5 , it contains discriminant validity (Fornell \& Larcker, 1981). For achieving construct validity, AVE should be higher than MSV (Maximum Shared Variance) and ASV (Average Shared Variance). 
All the above criteria were met for the measurement model. So, validity of the model was confirmed.

\section{Structural equation modeling (SEM)}

Structural equation modeling is a multivariate data analysis tools to examine the structural relationship among manifest variables (Structural equation modeling, 2017). SEM is the combination of exploratory factor analysis and multiple regression analysis. It allows to perform multiple and interrelated analysis at a time. It tests the relationship among exogenous and endogenous constructs in the structural model. SEM is run after testing the CFA. Figure 3 showed the structural model.

Figure 3: Structural Model

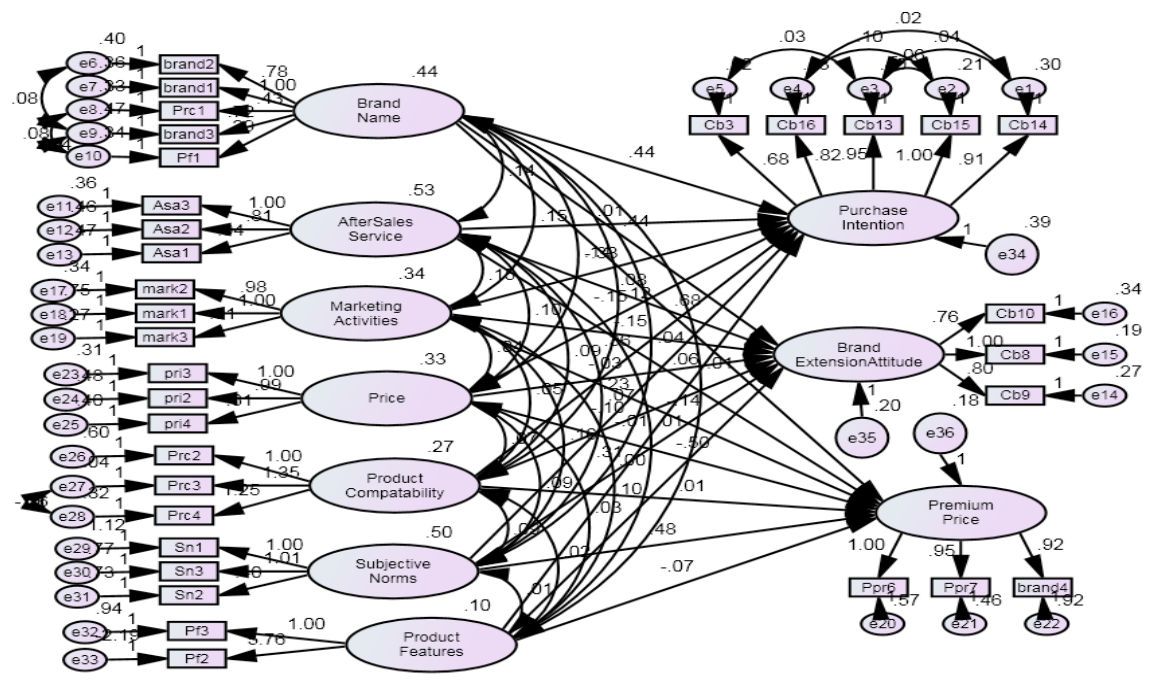

Squared multiple correlation of purchase intention (.266 or $26.6 \%$, brand extension attitude (.361 or $36.1 \%)$ and premium price $(.590$ or $59 \%$ ). It was said that prediction capacity of the structural model was explained 26.6 percent for brand image, 36.1 percent for brand extension attitude and 59 Percent for premium price.

\section{Hypothesis testing}

Relationship among consumer response/behavior constructs was tested. It was measured below. 
84 CUSTOMER RESPONSE TOWARDS SMART PHONES ...

Table 2: Relationship among Customer Response Dimensions (Purchase Intention)

\begin{tabular}{|c|l|c|c|c|c|r|l|}
\hline Path & \multicolumn{1}{|c|}{ From } & To & Estimate & S.E. & C.R. & P & Result \\
\hline $\mathbf{H}_{\mathbf{1}}$ & Brand Name & $\begin{array}{l}\text { Purchase } \\
\text { Intention }\end{array}$ & .439 & .110 & 4.005 & $* * *$ & Supported \\
\hline $\mathbf{H}_{\mathbf{2}}$ & $\begin{array}{l}\text { After Sales } \\
\text { Service }\end{array}$ & $\begin{array}{l}\text { Purchase } \\
\text { Intention }\end{array}$ & .006 & .082 & .070 & .944 & Supported \\
\hline $\mathbf{H}_{\mathbf{3}}$ & $\begin{array}{l}\text { Marketing } \\
\text { Activities }\end{array}$ & $\begin{array}{l}\text { Purchase } \\
\text { Intention }\end{array}$ & -.331 & .132 & -2.508 & .012 & Supported \\
\hline $\mathbf{H}_{\mathbf{4}}$ & Price & $\begin{array}{l}\text { Purchase } \\
\text { Intention }\end{array}$ & -.151 & .110 & 1.374 & .169 & $\begin{array}{c}\text { Not } \\
\text { Supported }\end{array}$ \\
\hline $\mathbf{H}_{\mathbf{5}}$ & $\begin{array}{l}\text { Product } \\
\text { Compatability }\end{array}$ & $\begin{array}{l}\text { Purchase } \\
\text { Intention }\end{array}$ & .355 & .098 & 3.619 & $* * *$ & Supported \\
\hline $\mathbf{H}_{\mathbf{6}}$ & $\begin{array}{l}\text { Subjective } \\
\text { Norms }\end{array}$ & $\begin{array}{l}\text { Purchase } \\
\text { Intention }\end{array}$ & .229 & .103 & 2.217 & .027 & Supported \\
\hline $\mathbf{H}_{7}$ & $\begin{array}{l}\text { Product } \\
\text { Features }\end{array}$ & $\begin{array}{l}\text { Purchase } \\
\text { Intention }\end{array}$ & -.010 & .072 & -.136 & .892 & $\begin{array}{c}\text { Not } \\
\text { Supported }\end{array}$ \\
\hline
\end{tabular}

The regression coefficients of brand name, marketing activities, product compatability and subjective norms on purchase intention were found significant. So, H1, H3, H5 and H6 were supported.

Regression coefficient of after sales service, price and product features on purchase intention were statistically insignificant. So, H2, H4 and $\mathrm{H} 7$ were not supported.

It was said that brand name, marketing activities, product compatibility and subjective norms were the influential factors for purchase intention of smart phones.

Table 3: Relationship among Customer Response Dimensions (Brand Extension Attitude)

\begin{tabular}{|c|l|l|c|c|c|c|c|}
\hline Path & \multicolumn{1}{|c|}{ From } & \multicolumn{1}{|c|}{ To } & Estimate & S.E. & C.R. & P & Result \\
\hline $\mathbf{H}_{\mathbf{8}}$ & Brand Name & $\begin{array}{l}\text { Brand Extension } \\
\text { Attitude }\end{array}$ & .443 & .093 & 4.764 & $* * *$ & Supported \\
\hline $\mathbf{H}_{\mathbf{9}}$ & $\begin{array}{l}\text { After Sales } \\
\text { Service }\end{array}$ & $\begin{array}{l}\text { Brand Extension } \\
\text { Attitude }\end{array}$ & .077 & .069 & 1.118 & .264 & $\begin{array}{l}\text { Not } \\
\text { Supported }\end{array}$ \\
\hline $\mathbf{H}_{\mathbf{1 0}}$ & $\begin{array}{l}\text { Marketing } \\
\text { Activities }\end{array}$ & $\begin{array}{l}\text { Brand Extension } \\
\text { Attitude }\end{array}$ & -.145 & .108 & 2.349 & .017 & Supported \\
\hline $\mathbf{H}_{\mathbf{1 1}}$ & Price & $\begin{array}{l}\text { Brand Extension } \\
\text { Attitude }\end{array}$ & -.031 & .092 & -.335 & .738 & $\begin{array}{l}\text { Not } \\
\text { Supported }\end{array}$ \\
\hline $\mathbf{H}_{\mathbf{1 2}}$ & $\begin{array}{l}\text { Product } \\
\text { Compatability }\end{array}$ & $\begin{array}{l}\text { Brand Extension } \\
\text { Attitude }\end{array}$ & -.098 & .077 & -1.279 & .201 & $\begin{array}{l}\text { Not } \\
\text { Supported }\end{array}$ \\
\hline $\mathbf{H}_{\mathbf{1 3}}$ & $\begin{array}{l}\text { Subjective } \\
\text { Norms }\end{array}$ & $\begin{array}{l}\text { Brand Extension } \\
\text { Attitude }\end{array}$ & .315 & .093 & 3.379 & $* * *$ & Supported \\
\hline $\mathbf{H}_{\mathbf{1 4}}$ & $\begin{array}{l}\text { Product } \\
\text { Features }\end{array}$ & $\begin{array}{l}\text { Brand Extension } \\
\text { Attitude }\end{array}$ & .098 & .062 & 1.567 & .117 & $\begin{array}{l}\text { Not } \\
\text { Supported }\end{array}$ \\
\hline
\end{tabular}


The regression coefficients of brand name, marketing activities and subjective norms on brand extension attitude were found significant. So, $\mathrm{H} 8, \mathrm{H} 10$ and $\mathrm{H} 13$ were supported.

Regression coefficient of after sales service, price, product compatability and product features on brand extension attitude were statistically insignificant. So, H9, H11, H12 and H14 were not supported.

It was said that brand name, marketing activities and subjective norms were the influential factors for brand extension attitude of smart phones.

Table 4: Relationship among Customer Response Dimensions (Premium Price)

\begin{tabular}{|c|c|c|c|c|c|c|c|}
\hline Path & From & To & Estimate & S.E. & C.R. & $\mathbf{P}$ & Result \\
\hline $\mathbf{H}_{15}$ & Brand Name & $\begin{array}{l}\text { Premium } \\
\text { Price }\end{array}$ & .683 & .131 & 5.199 & $* * *$ & Supported \\
\hline $\mathbf{H}_{16}$ & $\begin{array}{l}\text { After Sales } \\
\text { Service }\end{array}$ & $\begin{array}{l}\text { Premium } \\
\text { Price }\end{array}$ & .065 & .087 & .745 & .457 & $\begin{array}{c}\text { Not } \\
\text { Supported }\end{array}$ \\
\hline $\mathbf{H}_{17}$ & $\begin{array}{l}\text { Marketing } \\
\text { Activities }\end{array}$ & $\begin{array}{l}\text { Premium } \\
\text { Price }\end{array}$ & -.136 & .138 & -.986 & .324 & $\begin{array}{c}\text { Not } \\
\text { Supported }\end{array}$ \\
\hline $\mathbf{H}_{18}$ & Price & $\begin{array}{l}\text { Premium } \\
\text { Price }\end{array}$ & -.503 & .136 & -3.711 & $* * *$ & Supported \\
\hline $\mathbf{H}_{19}$ & $\begin{array}{l}\text { Product } \\
\text { Compatability }\end{array}$ & $\begin{array}{l}\text { Premium } \\
\text { Price }\end{array}$ & .011 & .097 & .110 & .912 & $\begin{array}{c}\text { Not } \\
\text { Supported }\end{array}$ \\
\hline $\mathrm{H}_{20}$ & $\begin{array}{l}\text { Subjective } \\
\text { Norms }\end{array}$ & $\begin{array}{l}\text { Premium } \\
\text { Price }\end{array}$ & .484 & .130 & 3.738 & $* * *$ & Supported \\
\hline $\mathbf{H}_{21}$ & $\begin{array}{l}\text { Product } \\
\text { Features }\end{array}$ & $\begin{array}{l}\text { Premium } \\
\text { Price }\end{array}$ & -.069 & .078 & -.890 & .373 & $\begin{array}{c}\text { Not } \\
\text { Supported }\end{array}$ \\
\hline
\end{tabular}

The regression coefficients of brand name, price and subjective norms on premium price were found significant. So, H15, H18 and H20 were supported.Regression coefficient of after sales service, marketing activities, product compatability and product features on premium price were statistically insignificant. So, H16, H17, H19 and H21 were not supported.It was said that brand name, price and subjective norms were the influential factors for brand extension attitude of smart phones.

\section{CONCLUSION}

The research was designed to measure the customer response/ behavior towards smart phone purchase in the Nepalese context. Brand 
name, marketing activities, and subjective norms are the most influential factors for customer response of smart phones for purchase intention, brand extension attitude and premium price. People are indifferent to after sales service and product features for showing customer response towards smart phone purchase. The study is partially consistent with (Dziwornu, 2013; Khan \& Rohi, 2013; Malviya, Saluja, \& Thakur, 2013; Lay-Yee, 2013; Mohan, 2014). Nepalese smart phone markets are full of varieties of brands. All people are known about the brand, product features and services given after the purchase. Consumer responses are mostly focused on purchase intention and brand extension attitude and least prefer to pay premium price. Product features and after sales services is important to product sales but customers are more focused to purchase of the brand only. Marketers should make strategies that customer should favor to brand extension besides purchase of the smart phones. Branding strategies is done to create unique, distinct and favorable image for the smart phones brands.

\section{WORK CITED}

Aaker, D. A. (1996). Building strong brand. New York: Free Press.

Anderson, J.C., \& Gerbing, D.W. (1988). Structural equation modeling in practice: A review and recommended two-step approach. Psychological Bulletin, 103(3), pp. 411-423.

Byrne, B.M. (2001). Structural equation modeling with AMOS: Basic concepts, applications and programming. Mahwah, New Jersey: Lawrence Erlbaum Associates.

Comer, J.C., \& Wikle, T.A. (2008). Worldwide diffusion of the cellular telephone: 1995-2005. The Professional Geographer, 60(2), pp. 252-269.

Das, D. (2012). An empirical study of factors influencing buying behavior of youth consumers towards mobile handsets: A case study in coastal districts of Odisha. Asian Journal of Research in Business Economics and Management, 2(4), pp. 68-82.

Dodds, W.B., Monroe, K.B., \& Grewal, D. (1991). Effects of price, brand, and store information on buyers' product evaluation. Journal of Marketing Research, 28(3), pp. 307-319. 
Dziwornu, R.K. (2013). Factors affecting mobile phone purchase in the greater accra region of Ghana: A binary logit model approach. International Journal of Marketing Studies, 5(6), pp. 154-155.

Fishbein, M., \& Ajzen, I. (1975). Belief, attitude, intention, and behavior: An introduction to theory and research. Addison-Wesley Publishing Company.

Gatignon, H., \& Robertson, T. (1985). A propositional inventory for new diffusion research. Journal of Consumer Research, (11), pp. 849867.

Hair, J.F. Jr., Anderson, R.E., Tatham, R.L., \& Black, W.C. (1998). Multivariate data analysis. New Jersey: Prentice Hall.

Isabella, G. (2012). Influence of discount price announcements on consumer's behavior. Journal of Business Administration, 5(26), pp. 657-671.

Joreskog, K., \& Sorbom, D. (1993). Structural equation modeling with the IMPLIS command language. Chicago: Scientific Software International (SSI).

Kapferer, J.N. (1997). Strategic brand management. London: Kogan.

Keller, K.L. (1993). Conceptualizing, measuring and managing customer based brand equity. Journal of Marketing, 57(1), pp. 1-22.

- - - (2003). Strategic brand management (2nd ed.). Upper Saddle River, NJ: Prentice Hall.

Khan \& Rohi. (2013). Investigating the factors affecting youth brand choice for mobile phones purchase. A study of private universities students of Peshawar. Management \& Marketing Challenges for the Knowledge Society, 8(2), pp. 369-384.

Kotler, P., \& Armstrong, G. (2010). Principle of marketing ( $3^{\text {rd }}$ ed.). Pearson Education.

Kotler, P., \& Keller, K.L. (2012). Marketing management. (14 ${ }^{\text {th }}$ ed.). Pearson Education.

Lay-Yee, K.L., Kok-Siew, H., \& Yin-Fah, B.C. (2013). Factors affecting smartphone purchase decision among Malaysizn Generation Y. International Journal of Asian Social Science, 3(12), pp. 24262440 . 
Loudon, D., \& Bitta, D. (1993). Consumer behavior: Concepts and applications (4th ed.). New York: McGraw Hill.

Malviya, S., Saluja, M.S., \& Thakur, A.S. (2013). A study on the factors influencing consumers' purchase decision towards smart phones in Indore. International Journal of Advance Research in Computer Science and Management Studies, 1(6), pp. 14-21.

Mohan, A. (2014). Consumer behavior towards smartphone industry in Indian market (Dissertation). MBA, Dublin Business School. Retrieved from http://esource.dbs.ie/bitstream/handle/10788/1812/ mba_mohan_a_2014.pdf? sequence $=1$

Osman, M. (2012). A study of the trend of smart phone and its usage behavior in Malaysia. International Journal on New Computer Architectures and Their Applications, 2(1), 274-285.

Phillips, P.L. (1998). Buying a brand: What you can't see can hurt you. Design Management Journal, 9(1), pp. 43-46.

Porter, M.E. (1974). Consumer behavior, retailer power and market performance in consumer goods industries. Review of Economics and Statistics, 56(4), pp. 419-436.

Schiffman, L.G., \& Kanuk, L.L. (2007). Consumer behavior (9 ${ }^{\text {th }}$ ed.). New Jersey: Prentice-Hall Inc.

Scitovsky, T. (1945). Some consequences of the habit of judging quality by price. Review of Economic Studies, 12, pp. 100-1005.

Solomon, M.R., \& Rabolt, N.J. (2009). Consumer behavior (2nd ed.). New Jersey: Prentice Hall. 